\title{
INTERFERENCE COMPETITION DRIVEN BY HYDRIC STRESS IN KOREAN HYLIDS
}

\author{
Amaël Borzée ${ }^{1,2}$, Yikweon Jang ${ }^{2}$ \\ ${ }^{1}$ Seoul National University, Republic of Korea \\ e-mail: amaelborzee@gmail.com \\ ${ }^{2}$ Ewha Womans University, Republic of Korea \\ e-mail:jangy@ewha.ac.kr
}

Received: 14.10.2017

\begin{abstract}
Competition is based on the type and importance of the resource sought, and interactions intensify with the importance of a given resource. One of the highest degrees of interference competition is physical interactions for a given resource. The treefrogs Dryophytes japonicus and D. suweonensis compete for spatial resources for the production of advertisement calls. Here, we have investigated a case of direct interference competition due to artificial hydric stress caused by variations in the irrigation system of rice paddies. Under this specific condition, an unusually high number of males of both species congregated in a single flooded field. We first found that males segregated following a demonstrated pattern, with $D$. japonicus on the edges and $D$. suweonensis at the centre of the submerged field. However, the differences in the distance to the edge of the submerged field for amplexuses of the two species were not significantly different. Due to the high number of individuals and the small size of the site, the area used by males of both species partly overlapped, and thus lead to physical interactions between two males of the two species. Dryophytes japonicus took over a calling site and managed to remove the opponent male. We sequentially described the interaction here, potentially representative of the general outcome of interference competition between these two species.
\end{abstract}

Key words: Dryophytes japonicus, Dryophytes suweonensis, interference competition, Korean Hylids, physical fight

\section{Introduction}

All organisms need resources and often these are in short supply, thus resulting in competition (Schluter, 2000). Although attenuated by specialisation and niche selection (Turelli et al., 2001), competition may lead to divergences over time (Lack, 1947; Schluter, 2000), and possibly speciation such as in Darwin's finches (Grant \& Grant, 2002). Competition can be further dichotomised between exploitative and interference competition. For instance, intraspecific interference competition in Rana utricularia Harlan, 1826 tadpoles supplanted exploitative competition (Steinwascher, 1978), and intraspecific visual interference competition played a role in larval development in $R$. kukunoris Nikolsky, 1918 (Yu \& Lambert, 2015). However, the two types of competition are nonmutually exclusive, as seen between Ambystoma talpoideum (Holbrook, 1838) and A. maculatum (Shaw, 1802) (Walls \& Jaeger, 1987) and between Rana temporaria Linnaeus, 1758 and Bufo calamita Laurenti, 1768 (Griffiths et al., 1991).
Interference competition between species occurs both directly and indirectly. An example of direct competition is between the larvae of the salamander Ambystoma maculatum and A. talpoideum, competing over hides (Walls, 1990). An examples of indirect interference competition is the production of growth inhibition chemicals by the tadpoles of Bufo calamita and Rana temporaria (Beebee, 1991). However, because of variations in species abilities to exploit resources, the impact of competition can be either symmetric or asymmetric (Begon et al., 2006). For instance, when in sympatry with Rana blairi (Mecham, Littlejohn, Oldham, Brown \& Brown, 1973), the length of the larval period will increase and the metamorphic body mass will decrease in $R$. areolata Baird \& Girard, 1852, while $R$. blairi will experience a drop in the number of metamorphosing individuals (Parris \& Semlitsch, 1998).

On the Korean Peninsula, Dryophytes japonicus (Günther, 1859) and D. suweonensis (Kura- 
moto, 1980) (previously Hyla; Duellman et al., 2016), are competing with each other for calling space in rice paddies. The calling space used by $D$. suweonensis is limited by the calling activity of D. japonicus, but not vice-versa (Kim, 2015; Borzée et al., 2016a,b). Here, we report the first case of interference competition between these two treefrog species. Physical encounter between calling males of the two species does not usually occurs due to habitat segregation (Borzée et al., 2016a), following historical differential use of the environment (Kim, 2016; Borzée et al., 2017). However, in this special case of human-induced hydric stress, the two species were brought in physical contact.

\section{Material and Methods}

This abnormal situation of hydric stress during the peak breeding season was observed on 27 June 2015 at 20:25 p.m. in Chungju, Judeokup, Jaenae-ri $618\left(36.989295^{\circ} \mathrm{N} ; 127.782439^{\circ} \mathrm{E}\right)$. Because of the lack of rain, most rice paddies had been drained by agricultural water, while a lone fallow field was flooded by a ruptured farming water hose (Fig.). The site was similar to the only natural site reported for Dryophytes suweonensis in term of spatial setting, but different by its vegetation (Borzée \& Jang, 2015). This attracted an abnormally high number of males and females from both Dryophytes species.
Spatial position of frogs and physical confrontation

For each calling frog within the submerged field, we recorded its position in relation to the edge of the submerged field with a range finder (SD 60; Sincon; Taichung, China), at $5 \mathrm{~cm}$ resolution. Data were collected for 10 male $D$. japonicus, two amplexed $D$. japonicus pairs, 16 male D. suweonensis and three amplexed $D$. suweonensis pairs. While measuring the distance to the edge of the submerged field for all calling individuals, we detected a male $D$. japonicus moving towards a calling $D$. suweonensis. We described sequence by sequence the resulting physical struggle between the two individuals.

\section{Statistical analysis}

To confirm the observation by Borzée et al. (2016b) on microhabitat segregation, we ran a MannWhitney $U$ test on the distance to the edges of the submerged field between the two species. Then, to assess the continuity of the pattern, we ran a MannWhitney $U$ test between the distances to edges of the submerged field for the amplexuses of the two species. Mann-Whitney U tests were selected due to the non-normal distribution of the data, but the similar shape of each dataset. All statistical analysis were run with SPSS v21.0 (SPSS, Inc., Chicago, USA), with $p$-values set at 0.05 for significance. The physical interaction between the males of the two species is described in the form of an ethogram.

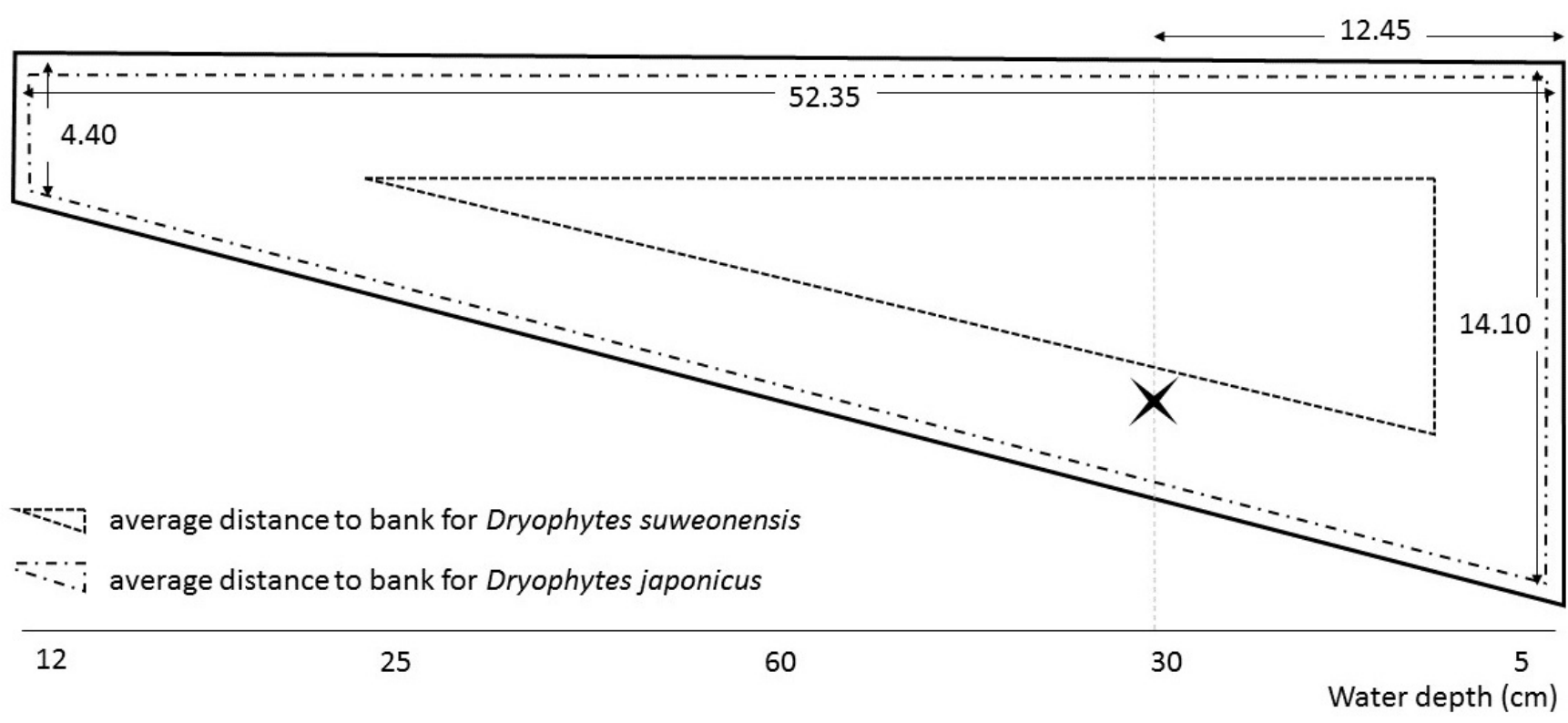

Fig. Line drawing of the site where the physical interaction between the two individuals took place. The inner-dotted-line is the average distance to the edge of the submerged field for Dryophytes suweonensis $(4.48 \mathrm{~m})$ and the outer-dotted-line is the average distance to the edge of the submerged field for D. japonicus $(1.79 \mathrm{~m})$. The star represents the place where the interaction between the two species took place. 


\section{Results}

The submerged field was trapezoidal, with the two parallel edges 4.40 and $14.10 \mathrm{~m}$ long, and the longest edge $52.35 \mathrm{~m}$ long (Fig.). The water was between 5 and $60 \mathrm{~cm}$ deep, with a modal depth of $40 \mathrm{~cm}$.

\section{Spatial positioning}

Male Dryophytes japonicus $(n=10)$ were on average $1.79 \pm 0.83 \mathrm{~m}$ (mean $\pm \mathrm{SD}$ ) away from the closest edges of the submerged field (range $=0.53$ $3.53 \mathrm{~m})$ and male $D$. suweonensis $(n=16)$ were on average $4.48 \pm 1.09 \mathrm{~m}$ away from the closest edge (range $=2.98-6.10 \mathrm{~m}$ ). This is a significant difference between the positions of the two species within the submerged field (Mann-Whitney U test; $U=5.00, Z=-3.95, p<0.001)$.

The amplexed $D$. japonicus pairs $(n=2)$ were on average $3.77 \pm 0.79 \mathrm{~m}$ away from the closest edge, while the amplexed $D$. suweonensis pairs ( $n$ $=3$ ) were on average $4.78 \pm 0.51 \mathrm{~m}$ away from the closest edge. The distance to the edge of the submerged field for the amplexus of the two species was not significantly different (Mann-Whitney $\mathrm{U}$ test; $U=1.00, Z=-1.15, p=0.248)$.

\section{Physical interaction}

The physical interaction between the males of the two species took place $3.05 \mathrm{~m}$ away from the edge, $12.45 \mathrm{~m}$ away from the longest of the two parallel edges (Fig.). This was within the overlap between the two species described above ( $2.98 \mathrm{~m}$ to $3.53 \mathrm{~m}$ away from the closest edge of the submerged field).

The male $D$. suweonensis was calling on a twig, roughly parallel to the water, $6.2 \mathrm{~cm}$ above water level (Table). The male D. japonicus jumped from the edge of the submerged field, swam towards the twig, and set to climb on it. Once within reach, the male $D$. japonicus attacked the male $D$. suweonensis, which had stopped calling when the competing male reached the twig. The male D. japonicus aimed at biting while «pushing/taking support» on the body of its opponent with its forelimbs. The attack stopped two seconds later, with the male $D$. japonicus taking two steps backward, and the two opponents staying immobile for four more seconds. The male $D$. japonicus then walked towards the male $D$. suweonensis, which took three steps backwards and jumped into the water. The total length of the event lasted seven seconds, from the first physical contact to the spontaneous self-withdrawal of the male $D$. suweonensis jumping into the water (Table). The male $D$. suweonensis escaped towards the centre of the water body and the male D. japonicus started producing advertisement calls 18 seconds later.
Table. Descriptive ethogram for the physical confrontation between the male Dryophytes japonicus and the male $D$. suweonensis. The calling activity displayed by either male before and after the confrontation is representative of the purpose of the fight: the acquisition of a calling perch

\begin{tabular}{ccc}
\hline Time (sec) & $\begin{array}{c}\text { Male Dryophytes } \\
\text { suweonensis }\end{array}$ & $\begin{array}{c}\text { Male Dryophytes } \\
\text { japonicus }\end{array}$ \\
\hline- & Calling & Swimming \\
- & Non-calling & Climbing on twig \\
0 & Immobile & Biting \\
2 & Immobile & Withdrawing \\
6 & Immobile & Immobile \\
7 & Jumping away & Moving forwards \\
18 & - & Calling \\
\hline
\end{tabular}

\section{Discussion}

Our observations report a second type of competition between Dryophytes japonicus and D. suweonensis: interference competition for calling sites, in non-natural conditions. At the difference with other studies (Kim, 2015; Borzée et al., 2016b), there was an overlap between the maximum distance to the edge of the submerged field for D. japonicus and the minimum distance to the edge for $D$. suweonensis. This overlap likely results from the hydric stress bringing all frogs together in an area where a ruptured water pipe flooded a fallow field. As the physical interaction took place within this area, we hypothesise that it was an artefact resulting from the human modifications to the landscape. This is also the highest number of $D$. suweonensis reported at a single calling site, and thus resulting in interference competition for a rarefied resource. We expect the size of the site not to be the key to the interpretation of these results, as segregation at smaller sites has been observed (Borzée et al., 2016b). However, the object of the competition, i.e. a calling perch, is readily understandable.

The male D. suweonensis escaping towards the centre of the water body, usually not populated by $D$. japonicus, follows the ecological knowledge on microhabitat use for these species. It is however interesting to note that although nonsignificant, the distance to the edge of the submerged field for the amplexuses of the two species follows the same segregation pattern. It is so far unclear if the low sample size is the reason for the non-significance in distance to the edge of the submerged field between the two species, or if females move around to lay eggs in a random fashion to increase offspring survivorship, such as in Bibron's toadlet (Pseudophryne bibronii Günther, 1859; Byrne \& Keogh, 2009). 
The outcome of the physical interaction may be the result of morphological differences between the two species as males $D$. japonicus are on average $5.22 \%$ larger than males of D. suweonensis for snout-vent length (Borzée et al., 2013). Another explanation is that despite male-male physical confrontations being common in $D$. japonicus, this is the first such observation for $D$. suweonensis and the species may not express this behaviour. Besides, the lack of behavioural answer from $D$. suweonensis to the attack by D. japonicus could be interpreted as the result of signals non-perceivable by the observer, such as chemical communication observed in reed frog species (Hyperoliidae; Starnberger et al., 2013). Our observations also potentially explain the dynamics for the numerous $D$. japonicus and the endangered $D$. suweonensis in Korea: when calling sites are limited, interference competition could be a contributing factor to the decline of $D$. suweonensis.

\section{Acknowledgements}

We are grateful to Yoonjung Yi for her comments on an earlier version of this manuscript. This work was financially supported by a research grant from The Biodiversity Foundation, a grant from the Rotary Club Lectoure-Fleurance to $\mathrm{AB}$, a grant from the Rural Development Administration of Korea (PJ012285) and a Research Grant by the National Research Foundation of Korea (\#2017R1A2B2003579) to YJ. The experiments in this study comply with the current law of the Republic of Korea.

\section{References}

Beebee T.J. 1991. Purification of an agent causing growth inhibition in anuran larvae and its identification as a unicellular unpigmented alga. Canadian Journal of Zoology 69(8): 2146-2153. DOI: 10.1139/z91-300

Begon M., Townsend C.R., Harper J.L. 2006. Ecology: from individuals to ecosystems. Oxford: Blackwell Publishing.

Borzée A., Park S., Kim A., Kim H.-T., Jang Y. 2013. Morphometrics of two sympatric species of tree frogs in Korea: a morphological key for the critically endangered Hyla suweonensis in relation to $H$. japonica. Animal Cells and Systems 17(5): 348-356. DOI: 10.1080/19768354.2013.842931

Borzée A., Jang Y. 2015. Description of a seminatural habitat of the endangered Suweon treefrog, Hyla suweonensis. Animal Cells and Systems 19(3): 1-5. DOI: 10.1080/19768354.2015.1028442

Borzée A., Kim J.Y., Da Cunha M.A.M., Lee D., Sin E., Oh S., Yi Y., Jang Y. 2016a. Temporal and spatial differentiation in microhabitat use: Implications for reproductive isolation and ecological niche specification. Integrative Zoology 11(5): 375-387. DOI: 10.1111/1749-4877.12200

Borzée A., Kim J.Y., Jang Y. 2016b. Asymmetric competition over calling sites in two closely related treefrog species. Scientific Reports 6: 32569. DOI: 10.1038/srep32569
Borzée A., Kim K., Heo K., Jablonski P.G., Jang Y. 2017. Impact of land reclamation and agricultural water regime on the distribution and conservation status of the endangered Dryophytes suweonensis. PeerJ 5: e3872. DOI: $10.7717 /$ peerj.3872

Byrne P.G., Keogh J.S. 2009. Extreme sequential polyandry insures against nest failure in a frog. Proceedings of the Royal Society of London B: Biological Sciences 276(1654): 115-120. DOI: 10.1098/rspb.2008.0794

Duellman W.E., Marion A.B., Hedges S.B. 2016. Phylogenetics, classification, and biogeography of the treefrogs (Amphibia: Anura: Arboranae). Zootaxa 4104(1): 1-109. DOI: 10.11646/zootaxa.4104.1.1

Grant P.R., Grant B.R. 2002. Adaptive radiation of Darwin's finches: Recent data help explain how this famous group of Galapagos birds evolved, although gaps in our understanding remain. American Scientist 90(2): 130-139.

Griffiths R.A., Edgar P., Wong A.-C. 1991. Interspecific competition in tadpoles: growth inhibition and growth retrieval in natterjack toads, Bufo calamita. The Journal of Animal Ecology 60(3): 1065-1076. DOI: 10.2307/5431

Kim M.Y. 2015. Testing exploitative competition of calling sites between sympatric hylid species in Korea. MSc. Thesis. Seoul: Ewha Womans University.

Kim Y.E. 2016. Differential antipredator behavior between Hyla japonica and H. suweonensis suggests separate evolution. MSc. Thesis. Seoul: Ewha Womans University.

Lack D. 1947. Darwin's Finches. Cambridge, UK: Cambridge University Press.

Parris M.J., Semlitsch R.D. 1998. Asymmetric competition in larval amphibian communities: conservation implications for the northern crawfish frog, Rana areolata circulosa. Oecologia 116(1-2): 219-226. DOI: 10.1007/PL00013822

Schluter D. 2000. Ecological character displacement in adaptive radiation. American Naturalist 156(S4): 4-16. DOI: $10.1086 / 303412$

Starnberger I., Poth D., Peram P.S., Schulz S., Vences M., Knudsen J., Barej M.F., Rödel M.O., Walzl M., Hödl W. 2013. Take time to smell the frogs: vocal sac glands of reed frogs (Anura: Hyperoliidae) contain species-specific chemical cocktails. Biological Journal of the Linnean Society 110(4): 828-838. DOI: 10.1111/bij.12167

Steinwascher K. 1978. Interference and exploitation competition among tadpoles of Rana utricularia. Ecology 59(5): 1039-1046. DOI: 10.2307/1938556

Turelli M., Barton N.H., Coyne J.A. 2001. Theory and speciation. Trends in Ecology \& Evolution 16(7): 330-343. DOI: $10.1016 / \mathrm{S} 0169-5347(01) 02177-2$

Walls S.C. 1990. Interference competition in postmetamorphic salamanders: interspecific differences in aggression by coexisting species. Ecology 71(1): 307-314. DOI: $10.2307 / 1940270$

Walls S.C., Jaeger R.G. 1987. Aggression and exploitation as mechanisms of competition in larval salamanders. Canadian Journal of Zoology 65(12): 2938-2944. DOI: 10.1139/z87-446

Yu T., Lambert M. 2015. Conspecific visual cues: the relative importance of interference and exploitation competition among tadpoles of Rana kukunoris. Ethology Ecology \& Evolution 29(2): 193-199. DOI: 10.1080/03949370.2015.1092477 


\title{
ИНТЕРФЕРЕНЦИОННАЯ КОНКУРЕНЦИЯ МЕЖДУ КВАКШАМИ (НYLIDAЕ) КОРЕИ, ОБУСЛОВЛЕННАЯ ВОДНЫМ СТРЕССОМ
}

\author{
А. Борзи ${ }^{1,2}$, Й. Джанг ${ }^{2}$ \\ ${ }^{1}$ Начиональный университет Сеула, Республика Корея \\ e-mail: amaelborzee@gmail.com \\ ${ }^{2}$ Женский университет Ихва, Республика Корея \\ e-mail: jangy@ewha.ac.kr
}

\begin{abstract}
Конкуренция основана на типе и важности запрашиваемого ресурса, а взаимодействие усиливается с учетом важности данного ресурса. Одной из наивысших степеней интерференционной конкуренции является физическое взаимодействие за данный ресурс. Древесные лягушки Dryophytes japonicus (обычный вид) и D. suweonensis (исчезающий вид) конкурируют за пространственные ресурсы для осуществления призывных сигналов. Мы рассмотрели случай прямой интерференционной конкуренции из-за искусственного водного стресса, вызванного изменениями в системе орошения рисовых полей. В этих специфических условиях было представлено необычно большое количество самцов обоих видов, собранных на одном затопленном поле. Сначала мы обнаружили, что самцы распределены по следующей схеме: с D. japonicus по краям и D. suweonensis в центре обводненного поля. Однако не было значительных различий в расстоянии до края поля для представителей обоих видов. Из-за большого числа особей и небольшого размера участка области, используемые самцами обоих видов, частично перекрывались, что, таким образом, приводило к физическому взаимодействию между самцами двух видов. В результате Dryophytes japonicus смог занять место для призывных криков и вытеснить самца-соперника. Мы последовательно описали здесь взаимодействие, потенциально представляющее общий результат интерференционной конкуренции между этими двумя видами.
\end{abstract}

Ключевые слова: Dryophytes japonicus, Dryophytes suweonensis, интерференционная конкуренция, корейские квакши, физическая борьба 